\title{
JOURNALISTIC WRITING ON PRINTED AND ONLINE PRESS: TOWARDS A CHANGE OF ENUNCIATIVE CONTRACT?
}

\begin{abstract}
Justine Simon ${ }^{1}$
In order to examine journalistic writing, using enunciative studies and argumentation's tradition of discourses analysis, we present a comparative study of papers published just after the election of the $44^{\text {th }}$ President of United States, Barack Obama, on November $4^{\text {th }}$ of 2008 , in printed and online newspapers. We aim to see if there is a real difference of enunciative contract between printed and online press, to contribute to a current question concerning the deep changes of journalistic writing induced by new technologies. Starting with a corpus of three French daily national newspapers (Le Monde, Libération and Le Figaro), both in printed and online versions, and three online pure players (Rue89.com, LePost.fr and Mediapart.fr), we try to show that a keen observation of the journalists' enunciative positions, towards the opinions they put in their speech, enlightens the interpretation of those contracts.
\end{abstract}

We intend to analyze journalistic writing with two methods: enunciative analysis of discourses (Rabatel, 2004) and argumentation in discourses (Amossy, 2000). For this purpose, we perform a comparative study of several articles published the day after the election of the US $44^{\text {th }}$ President, Barack Obama, on November $4^{\text {th }}$ of 2008 , some in printed newspapers, others in online ones.

Through the scope of the "journalistic contract of enunciation" (Charaudeau, 2006), the various ways of "enunciative retiring" (Vion, 1998, p. 197) used in printed press have been often analyzed by several

1 Justine Simon est Maître de Conférences au Centre de Recherches sur les Médiations à l'Université de Lorraine.

Recherches en communication, $\mathrm{n}^{\circ} 40$ (2013). 
researchers (Charaudeau, 2006; Maingueneau, 2004; Rabatel, 2004; Simon, 2012; Tuomarlà; 1999). However, very few studies aim to analyze the enunciative contracts agreed in the field of online press systems of communication. This kind of contract, among online press journalists seems to cope a priori with a claim of higher subjectivity than usually used in the field of printed press, in order to obtain "a kind of sincerity and transparency towards the public" (Cardon, 2010, p. 73). Concerning this point, Cardon evokes a "crisis of the distanced journalistic writing" (Cardon, 2010). In order to contribute to the current collective reflection about the deep transformations of journalistic writing induced by new technologies, our purpose is to examine if a break really exists between printed press - or "reporting journalism" (Brin \& et. al., 2004), i.e. implementing a rhetoric of objectivity - and online press - or "communicational journalism" (Brin \& et al., 2004) clearly assuming its subjectivity.

For that purpose, we choose to study the enunciative marks of the "representation of the other's discourse" (Authier, 2004), which can be found through the whole collection of articles published in printed and online press on $5^{\text {th }}$ and $6^{\text {th }}$ of November 2008 . We try to show that a keen observation of the enunciative options of journalists, towards the opinions they relate in their discourses, may give some interpretation's leads of those enunciative contracts.

First, we set out the subject of this study, going into the problem of "enunciative contract", defining our working hypothesis, raising some epistemological obstacles, and describing what can be observed. Second, we expose the results of analysis of various modes of relating "the others" discourses, identified through several degrees of objectivization and subjectivization.

\section{Theoretical and methodological framework}

\section{1. Subject of this study}

\section{1. 1. Media coverage}

First of all, we give a global outline of media coverage in terms of political context, demarcation of temporality, choice of press titles, kinds of media and quantity of published papers.

The election of President Barack Obama on November $4^{\text {th }}$ of 2008 gives the political context. The demarcation of temporality within the 
texts of our corpus precisely depends on that context, since online articles have been published the day after in France, while printed articles could only be published on November 6th. Our corpus is limited to three newspapers of national daily press (Le Monde, Libération and Le Figaro), offering both printed and online issues and using two kinds of journalistic processing of information. The acronym $O L I-$ On-Line Issued - (in French: "mis en ligne", MEL, (Mercier, 2010)) will refer to these online issues (LeMonde.fr and Liberation.fr since 2005; LeFigaro. fr since 2006). Concerning these three OLI, the issues of November $5^{\text {th }}$ have been selected. However, we also included in our corpus those of November 6th, because printed articles were published at this date. Three other newspapers, referred as $O L B$ (for "On-Line Born", "Nés En Ligne" - NEL - in French (Mercier, 2010)), will also be analyzed, namely Rue89.com (first issue on May 2007), LePost.fr (September 2007; renamed HuffingtonPost.fr in January 2012) and Mediapart.fr (March 2008).

Let us specify that, unlike printed press records which preserve the original layout, the ones of digital issues can change from the day of publication to the day they are read. Therefore, when collecting a corpus a posteriori (in our case: three years after the events), we must assume that those records have been re-formatted according to the evolution of editorial options and graphic standards of newspapers. This includes changes put in hierarchical organization and linking paths, putting iconic and/or textual links to various social networks, adding new internal and external links, etc.

In our whole corpus, printed press counts most published articles. Comparatively to Liberation.fr, the amount of articles published by online versions of LeMonde.fr and LeFigaro.fr seems rather weak, knowing that our observation spreads along two days. LePost.fr shows the largest media coverage among OLB. Most articles are written by journalists belonging to the editorial staffs, except for LePost.fr. The ratio of articles written by other contributors is a little higher in OLB than in OLI (perhaps the authors are subscribers or experts invited by the editorial staffs). Structurally, the print media does not authorize to add comments, but as for online press, we note that all articles published by OLB press induced a high ratio of reader's participation. 


\begin{tabular}{|l|l|c|c|c|c|}
\hline \multirow{2}{*}{$\begin{array}{c}\text { Types of } \\
\text { medias }\end{array}$} & $\begin{array}{c}\text { Titles of } \\
\text { newspapers }\end{array}$ & $\begin{array}{c}\text { Total of } \\
\text { articles }\end{array}$ & $\begin{array}{c}\text { Total of ar- } \\
\text { ticles written } \\
\text { by the edito- } \\
\text { rial staff }\end{array}$ & $\begin{array}{c}\text { Total of } \\
\text { articles writ- } \\
\text { ten by other } \\
\text { contributors }\end{array}$ & $\begin{array}{c}\text { Total of } \\
\text { com- } \\
\text { ments }\end{array}$ \\
\hline \multirow{3}{*}{$\begin{array}{l}\text { Printed } \\
\text { press }\end{array}$} & Le Monde & 39 & 35 & 4 & 0 \\
\cline { 2 - 6 } & Libération & 45 & 29 & 16 & 0 \\
\cline { 2 - 6 } & Le Figaro & 31 & 29 & 2 & 0 \\
\hline \multirow{4}{*}{ OLI press } & LeMonde.fr & 16 & 16 & 0 & 76 \\
\cline { 2 - 6 } & Liberation.fr & 63 & 43 & 20 & 1802 \\
\cline { 2 - 6 } & LeFigaro.fr & 22 & 20 & 2 & 962 \\
\hline \multirow{4}{*}{ OLB press } & Rue89.com & 7 & 5 & 2 & 880 \\
\cline { 2 - 6 } & LePost.fr & 40 & 15 & 25 & 1415 \\
\cline { 2 - 6 } & Mediapart.fr & 8 & 7 & 1 & 221 \\
\hline \multicolumn{2}{|c|}{ Total printed press } & 115 & 93 & 22 & 0 \\
\hline \multicolumn{2}{|c|}{ Total OLI press } & 101 & 79 & 22 & 2840 \\
\hline \multicolumn{2}{|c|}{ Total OLB press } & 55 & 27 & 28 & 2516 \\
\hline
\end{tabular}

Table 1. Media coverage

\section{1. 2. Main comparative lines}

The corpus consists of several subsets allowing a two-dimension comparative analysis. The $1^{\text {st }}$ main line, considering print media and OLI media, allows a comparative analysis of features linked to media specificity. The $2^{\text {nd }}$ main line brings to light differences and similarities between our nine newspapers.

\section{2. Research questions}

The notion of "contract of enunciation" (or "enunciative contract"), inherited from that of "contract of reading" formulated by Verón (1985), will be useful. Taking into account the enunciative marks, it will enable to raise a hypothesis about the type of commitment characterizing communicational interchanges. In other words, analysis of "production's modes of discourses", as Charaudeau (2006) says, aims to understand the kinds of contracts proposed by printed or online newspapers at the level of production's conditions of discourses. Therefore, the enunciative contract is the central point of this study. We can formulate our research question as follows: are there differences between the types of enunciative contracts proposed by printed and online press? 


\section{3. Hypothesis}

The first assumption is linked to the media specificity. In the case of OLI press, we assume that the process of discourses' production is almost identical to that of the printed press:at first glanceFrom a first look, it seems to be a mere transposition of published articles from printed to online press. A contract of objective enunciation might mainly rule these two media. However as for OLB press, we think that the writing process would have been thought in a more complex way, according to the possibilities offered by the digital medium. Therefore, the enunciative contract would aim more towards the subjectivity in order to establish more proximity with the readers.

Our second assumption moderates the first one by supposing that, according to the kind of contributor, the writing would be radically different. Indeed, we suppose that the rhetoric of objectivity would be preferred by professional journalists.

\section{4. Epistemological obstacles}

\section{4. 1. Categorization in genres}

One of the main obstacles we had to face is that of journalistic genres. Our corpus consists of various publications and therefore receives a priori very distinct contracts.

With the help of categorization published in the textbook of journalistic writing of Grevisse (2008, pp. 97-180) we could identify marks of genre, i.e. elements of "editorial paratext" (Genette, 1987), since they did not systematically appear around the articles. This categorization, which offers three degrees of objectivization and subjectivization in reporting (objectivatingobjectivizing genres, genres requiring a self-investment of the journalist and subjectivating genres), has a pedagogical role: Grevisse insists on the fact that those genres are open. For instance, concerning the report, the adopted point of view may be objectivatingobjectivizing when reporting according to an external narrator, or subjectivating when the facts are internally focused and told through the sight of a character. During the exploratory analysis of our corpus, the labeling of those genres was not easy. Some problems arose, e.g. the difference between a tribune and an article written by an invited contributor. For that reason, we remain careful towards this 
re-appropriation which only aims at giving an overview of the global journalistic processing.

At a macro level, this categorization is helpful to suppose that three types of contracts may be established between the newspapers and their readers: 1) objectivatingobjectivizing enunciative contract, 2) subjectivating enunciative contract using personalization, 3) subjectivating enunciative contract with opinion. However, we must specify that this postulate has to be confronted with the results of analysis of discursive marks at micro level. An objectivatingobjective journalistic enunciative contract seems $a$ priori to be received in the most part of the articles issued by the printed and OLI press. The factual genres, such as analysis which implies the self-disengagement of journalists, are most represented indeed. Obama's election is then handled by a number of articles with personalized genres. The report, the interview, the portrait, which ask for more a subjective investment of the journalist, have an important place in printed and OLI press. Besides, these genres have nearly the same distribution as that of factual genres in OLB press. Finally, it is also among OLB press articles that the subjectivating enunciation's contract seems to be most present. Indeed, even if we meet only few leading articles in this type of media, genres implying the journalist's self-commitment and opinion, such as chronicles or funny bills, have been found mostly.

\section{4. 2. Eliminating anormative conception}

The definition of the enunciative contract raises another epistemological obstacle. Unlike Charaudeau (2006), who considers that the only journalistic enunciative contract implies the disappearance of the journalist's self-commitment in enunciation, we consider that several enunciative contracts may be agreed upon. Some genres receive a contract of enunciative objectivization, while others imply the journalist's self-commitment expression. Considering the notion of contract from this point of view eliminates axiological considerations concerning the writing practices. By reading Charaudeau, we perceive an implicit ethical judgment, from which we disagree. He states that "the ethical purpose obliges the agency of production to handle the information, to relate and comment on the events in a most credible possible way" (2006, p. 32). This only finality is radically opposed to the will of trapping the readers, thought in terms of drift: 


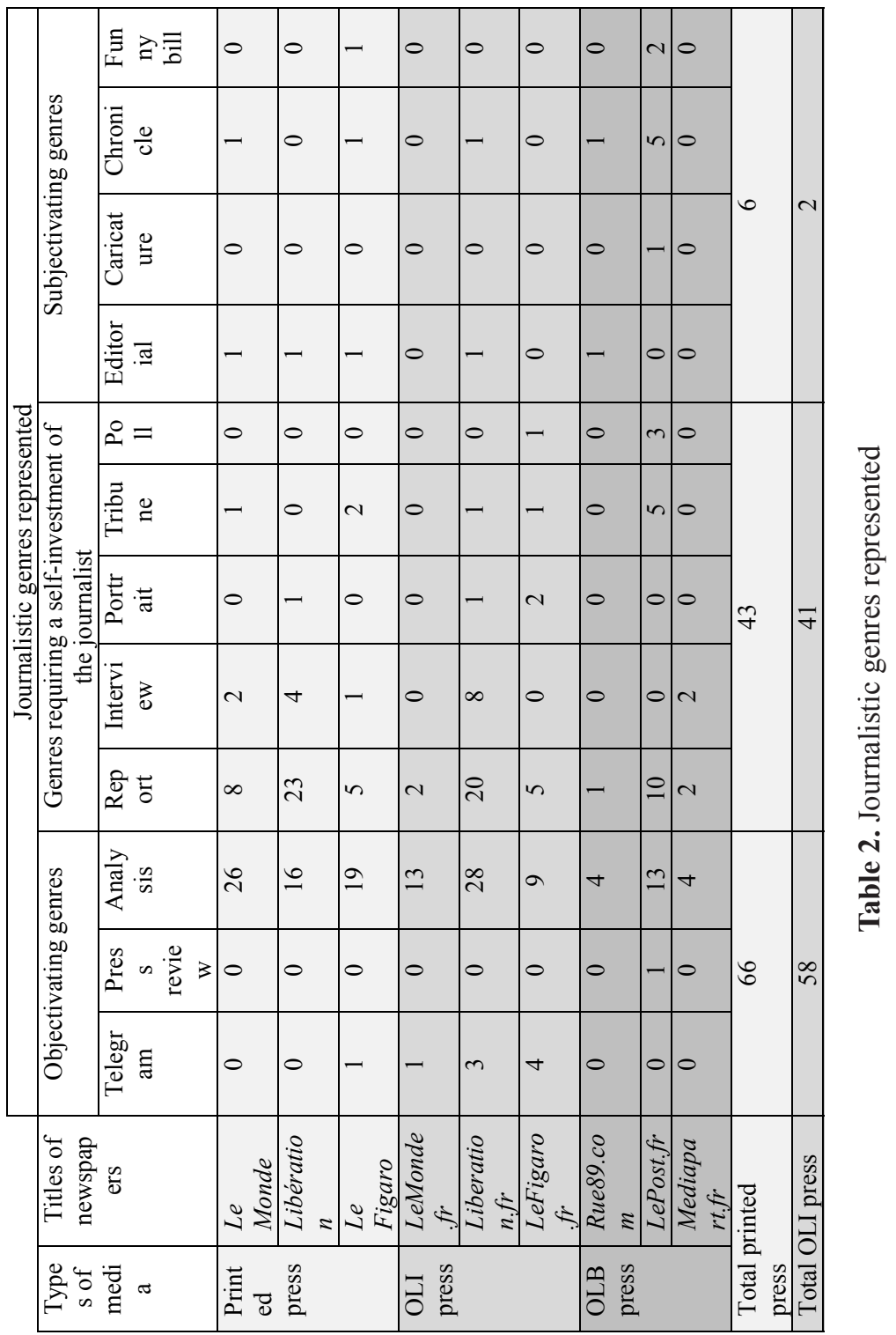


When the stake in trapping is dominant - and it is often so the informative aim disappears for the benefit of a game of exhibition - staging and dramatization. At the end, it produces drifts, which no longer cope with the requirement of ethics which is that of the civic information. (Charaudeau, 2006, p. 36). [Author's translation]

This asks the question of ethical norms related to the quality of journalistic writing, constituting a real epistemological obstacle for our analysis. Our purpose is not to find what should be the good use in journalism. We think that the enunciative disengagement is not necessarily a guarantee of quality. Therefore, getting around this question will allow us to propose only descriptive ideas, with as much objectivity as possible.

\section{5. Observable contents}

In order to interpret the types of enunciation contracts, we can observe numerous marks of objectivization and subjectivization. The distance or the commitment of a journalist can be analyzed through: the choice of appellations (nouns, adjectives and neutral, evaluative or emotional verbs), the use of modal marks such as deixis of person, the choice of enunciative sources, or the choice of the mode of representation of these.

Mouriquand says in the introduction of his book: "the journalistic writing has to be in the convergence of a reading for pleasure and an exact reporting" (1997, p. 3). Examination of the representation's modes of enunciative sources really makes sense, because these representations have two purposes: bring to life and accredit.

The enunciative marks that we choose to examine are declined in several types of observable phenomena: representations of the speech coming from elsewhere, and those in resumption. Let us specify that our analysis of discourses will be mainly qualitative, but it could also allow manual quantification.

First of all, we shall follow Authier (2004, p. 41) when she enumerates the four enunciative modes of representation of the other's discourses: the indirect speech, the direct speech, the modal shaping of the speech as second discourse, the autonymic modal shaping of borrowings. Each of these modes shows the marks of a not assumed 
personal point of view. They are presented below according to the decreasing degree of objectivization.

The direct speech (DS) seems to be the most literal way to record the speech of others, giving an illusion of objectivity. Overmarking (use of quotation marks, italics, specific insert) often contributes to reinforce this objectivatingobjectivizing aim. However, this mode may paradoxically show that the reporting speaker (journalist or external contributor) takes care of the original speaker's point of view (in example (1), Andrea Kalpasti's one), subjective indications of interpretation being present on the discourse framing the reported talk. For instance:

(1) Andrea Kalpasti, 19 years old, a student at Hunter College, who voted for the first time, calls his parents: "That's a step forward to cure the wounds of this country. For us young people, Obama is from our generation, all the friends of my age have voted, and we show that we are concerned by the future of this country. Yes we can..." (Libération, 06/11/2008, p. 17).

In the autonymic modal shaping of borrowings (AMSB), the borrowed talks are processed both in use and in mention, such as in textual blocks - of which one can find an example at (3) - where the reporting speaker generally rephrases the beginning of the reported speech and then puts at a distance the rest of the speech by means of formal marks (italics and/or quotation marks). At first sight, the AMSB configuration seems to produce an important effect of putting at a distance but in fact, like DS, it may strategically be used to introduce a thought about the reported speech.

(2) Moreover, in his first project of the Declaration of Independence, Thomas Jefferson, one of the founder fathers, denounces slavery, "this cruel war against human nature". (Le Figaro, 06/11/2008, p. 6)

(3) Barack Obama noted the overwhelming victory which the millions of Americans who voted in favor of the "change" the democratic candidate promised them during the campaign offered him. (Le Monde, 06/11/2008, p. 4)

The modal shaping of the speech as second discourse (MSSD) is a kind of indirect speech, but the reporting speaker distances himself from 
the point of view of the original speech by means of mediation frame marks (modal shaping by the conditional mode, use of the mediation mark according to, modal shaping using verbs attributing the talks to the original speaker, such as to claim, to insinuate, to intend, etc. For example, using the verb "to intend" is here usefull here for the reporter to show that he has no confidence in Obama's promise:

(4) Iraq. Mr. Obama intends to remove the main part of the American troops in sixteen months, by the end of July, 2010, to maintain in Iraq only forces in charge of counter-terrorism. (Le Monde, 06/11/2008, p. 10) [Author's emphasiswe underline]

The indirect speech (IS) is based on the rephrasing of the talks of the initial speaker by the reporting speaker. Since this mode is not faithful to the original speech, and does not use the distance markers, it may commit the reporting speaker's responsibility in a significant manner. There is a difference here between "John Mc Cain recognizes his defeat" and "John Mc Cain seems to recognizes his defeat". With IS, the affirmation is more assumed by the reporter.

(5) John McCain recognizes his defeat at Phoenix and calls the Americans to union. (Le Monde, 06/11/2008, p. 6)

Now we turn to the discourses in resumptionwhich contribute to a dynamics of talk-to-talk circulation (see Rosier, 2008). The discourse represented in resumption emphasizes a part of or the whole discourse originally represented in the body of the article. In this phenomenon of resumption, the other discourse is represented twice in the page: the first time in the original article (Original Represented Discourse, ORD), the second time it is represented again in the verbal paratext of the article by the phenomenon of resumption (Resumption-Represented Discourse, RRD). When reproducing the ORD, and often transforming it, the reporting speaker instrumentalizes it to turn it into an event of speech, and therefore increases the degree of subjectivization. This is an example where the ORD (6') is re-appropriated and set to a catchy title: the anti-rumors shield (6):

(6) Robert Gibbs. Possible Director of press-relations The anti-rumor shield 
(6') His favorite formula is "If you do not fight a rumor, it becomes the truth." (Libération, 06/11/2008, p. 9)

The addition of this RRD in the paratext results in a collective journalistic practice. RRD do not seem to be due to the journalist, but rather due to the editorial staff. The making-up of information is done at the scale of the page: the choice of the physical shape of the article and the addition of paratextual elements offal within the competence of the editorial staff who aims to deliver more dynamic information.

Finally, we take into account two types of observable contents in our analysis: the occurrences of the other's hyper-marked discourses deprived of contextual field allowing the interpretation and the open positioning of the reporting speaker towards the points of view defended in the represented the other's discourses.

\begin{tabular}{|c|c|c|c|c|}
\cline { 2 - 5 } \multicolumn{1}{c|}{} & $\begin{array}{c}\text { High degree of } \\
\text { objectivization }\end{array}$ & $\begin{array}{c}\text { Moderate } \\
\text { degree of } \\
\text { objectiviza- } \\
\text { tion }\end{array}$ & $\begin{array}{c}\text { Moderate } \\
\text { degree of sub- } \\
\text { jectivization }\end{array}$ & $\begin{array}{c}\text { High degree } \\
\text { of subjectivi- } \\
\text { zation }\end{array}$ \\
$\begin{array}{c}\text { Obser- } \\
\text { vable } \\
\text { contents }\end{array}$ & $\begin{array}{c}\text { Representations } \\
\text { of the other's } \\
\text { hyper-marked } \\
\text { discourses } \\
\text { deprived of } \\
\text { contextual field } \\
\text { allowing inter- } \\
\text { pretation }\end{array}$ & $\begin{array}{c}\text { Represen- } \\
\text { tations of } \\
\text { the other's } \\
\text { discourses } \\
\text { marked by a } \\
\text { personal non- } \\
\text { assumed point } \\
\text { of view }\end{array}$ & $\begin{array}{c}\text { Representa- } \\
\text { tions of the } \\
\text { other's dis- } \\
\text { courses in } \\
\text { resumption, } \\
\text { contributing to } \\
\text { a subjectivat- } \\
\text { ing shaping }\end{array}$ & $\begin{array}{c}\text { Open position- } \\
\text { ing of the re- } \\
\text { porting speak- } \\
\text { er towards the } \\
\text { points of view } \\
\text { defended in } \\
\text { the represen- } \\
\text { tation of the } \\
\text { other's dis- } \\
\text { courses }\end{array}$ \\
\hline
\end{tabular}

Table 3. Degrees of objectivization and emphasis of the subjectivity

Thus, in order to catch a critical sight on the discursive practices of representation of the the other's discourse, we propose the following gradual grid of observations presenting several degrees of neutralization and emphasis of the subjectivity: 


\section{The results of enunciative analysis}

\section{1. Overview}

The following table gives an overview of the results of observable contents that we have just described, among the nine titles of press selected for this study:

From a global point of view, we must raise some remarks. We find very few representations of the other's hyper-marked discourses - we mean totally deprived of contextual field allowing the interpretation among the three types of media. Concerning the modes of representation of the other's discourses, DS and AMSB modes are most used, therefore the aim of objectivization predominates. The representations in resumption of the other's discourses, which contribute to the subjectivization of the stage, are mostly used in printed press discourses, especially by Libération (both in printed and online issues). Besides, we meet more speakers open points of view towards the represented the other's discourses in OLB press than elsewhere. We did no't check differences in any one article or in the discourse of any one author, these observations concern all the media studies.

As a matter of fact, to answer partially our two initial hypotheses, we can globally assert, on the one hand, that there is a great similarity between the processing of printed press and that of OLI press. Despite of some differences due to the medium, which we shall discuss bellow, we can say that the discursive practices are almost identical from one support to another. Moreover, on our whole corpus, 2 articles of LeFigaro. $f r, 3$ of LeMonde. fr and forty of Liberation. $f r$ are similar to their printed version. On the other hand, the $15 \%$ of observed enunciative marks with moderate and strong degrees of subjectivization seem a somewhat low to confirm the idea of a subjectivating enunciative contract in the OLB press. Besides, we can validate our second hypothesis of a radically different style of writing according to the type of contributor, since the appeal to a linguistic politics of objectivization of the speech in the representations of the other's discourses is practically observed only in articles drafted by professional journalists.

Now, let us examine several examples to deepen the analysis of these results 


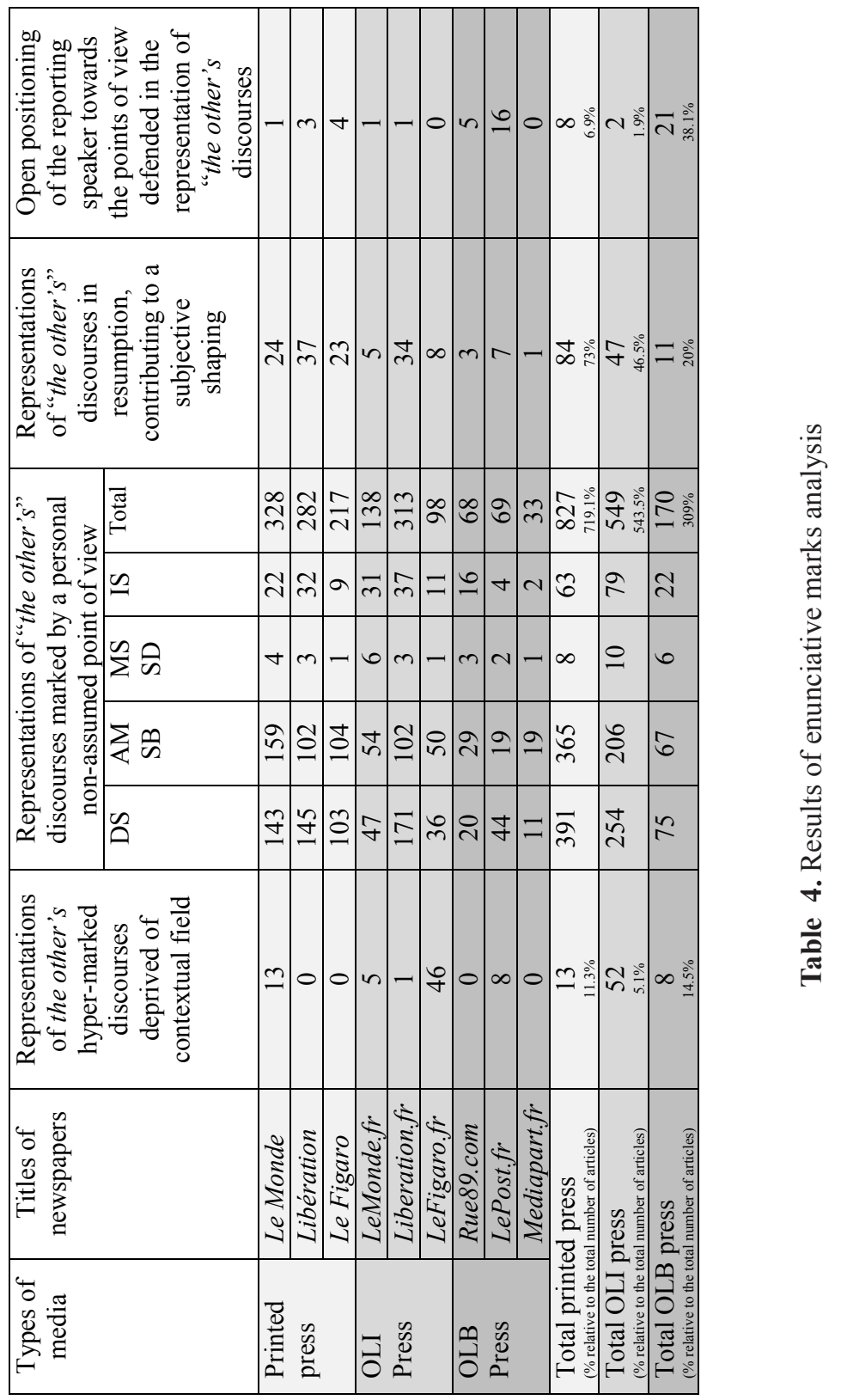




\section{2. Representations of hyper-marked discourses}

The representation of the the other's discourse in the direct mode, which does not use verbs specialized in the reporting of a talk, can be realized in an enunciative space by means of an insert box, as in image 1. This special insert is designed in the layout of the article in order to give the illusion of objectivity. In this case, the reporting speaker only mentions the original speaker of the represented discourse: "Denis Lacorne".

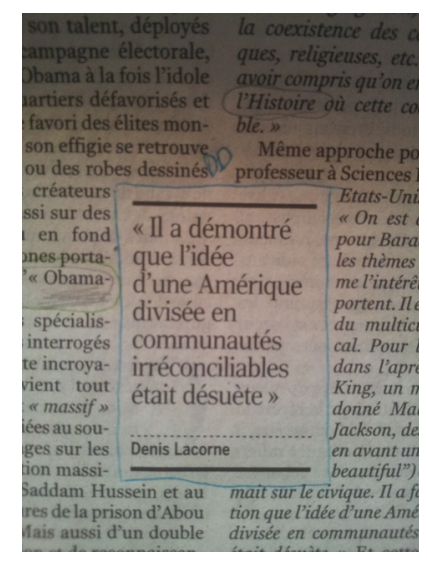

"He demonstrated that the idea of America divided into inappeasable communities was obsolete"

Image 1. Representation of an hyper-marked the other's discourse in an insert box (Le Monde, 06/11/2008, p. V)

The use of an insert box is a specificity of the printed press but we find others representations of hyper-marked discourses, as in LeFigaro. $f r$. This is an example, where the official function of the original speaker is mentioned:

(7) - Bertrand DELANOE, mayor of Paris:

"The great American people (...) dared a great historic change" (LeFigaro.fr, 05/11/2008, 19: 59) 
We meet hyper-marked representations of samples of Obama's speech in the narrative processing of a report by Le Monde, which aim both at objectivization and trapping. This is an example:

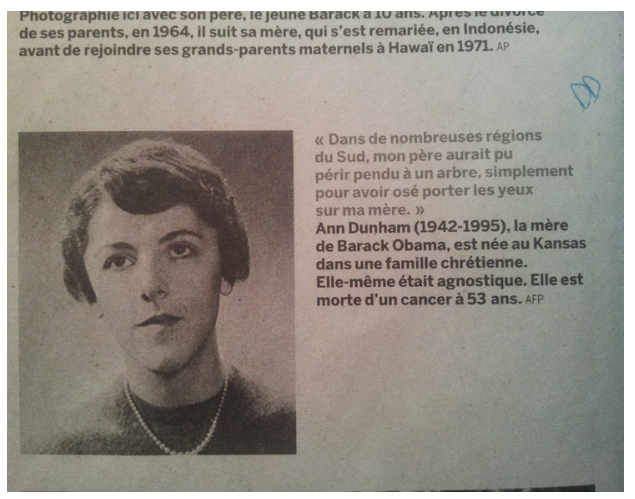

"In numerous regions of the South, my father could have died hung on a tree, simply for having dared raising his eyes at my mother." Ann Dunham (19421995), Barack Obama's mother, was born in Kansas in a Christian family. She herself was agnostic. She died of a cancer at the age of 53.

Image 2. Representation of an hyper-marked discourse juxtaposed with a photography (Le Monde, 06/11/2008, p. II)

The complementarity between image and text is considerable here. The photography plays a leading part to relate information and the represented speech keeps its effect of authenticity. Let us specify that among the whole corpus, it seems that this reflection on the effects of senses produced by juxtaposition of texts and images at the level of the newspaper's page goes less deep when OLI press is concerned. Articles stemming from the printed version transposed online lose in attractiveness to line up only to the rank of a little fascinating archive. This observation may be explained by the fact that the editorial staffs of newspapers had not established editorial teams completely dedicated to the online journalistic writing (about this point, see Charon \& Le Floch, 2011, pp. 48-53).

Barack Obama's speech was in the center of the media processing after its election. Several OLI titles of press, such as Liberation. fr, LeFigaro.fr and LeMonde.fr, published video samples in order to produce effects of instantaneousness and authenticity. 


\section{Le discours de Barack Obama}

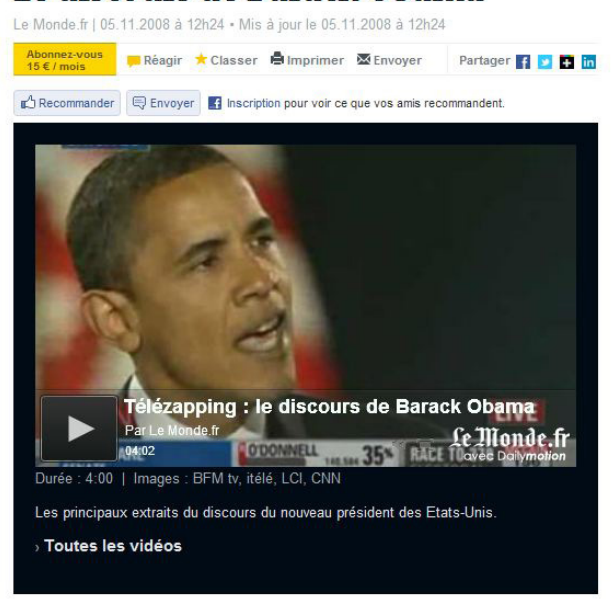

Image 3. Representation of an hyper-marked audio-visual "the other's" discourse (LeMonde.fr, 05/11/2008, 12: 24)

In this kind of representation, a new authority of mediation most often of media nature - appears, like Dailymotion in image 3. Although selected and split up, the represented speech is isolated from any contextualization which would influence the interpretation. A raw video is delivered. This audiovisual representation is a new means offered to editorial staffs specialized in the online press, giving them the possibility of guaranteeing strong effects of objectivity.

Contrary to what could be thought, the titles of OLI press could seize this opportunity to offer to their readers a more semiotically heterogeneous treatment, and therefore more attractive, of Obama's election. In the same way, sound sources are run, like in an article of LeFigaro.fr which emphasizes the reactions of several political personalities of Africa (in 2008/11/05, 20: 22), giving a playful and interactive aspect to the processing. Shifting to the digital device represents a decisive stage in the evolution of journalistic writing because it produces a discourse using several types of codes (in French: "discours pluricodé", see Peytard, 1993) involving textual, visual, audiovisual and sound sources.

To complete this point, let us give an example of hyper-marked discourse of the other's giving the illusion of non-intervention. This concerns a graphic representation of the results of a poll proposed by 
LePost.fr. The quantification in percentages and the graphics participate in the claimed effect of objectivity, although we think that the obtained effect is far from giving a credible vision of the opinion of the pooled public:

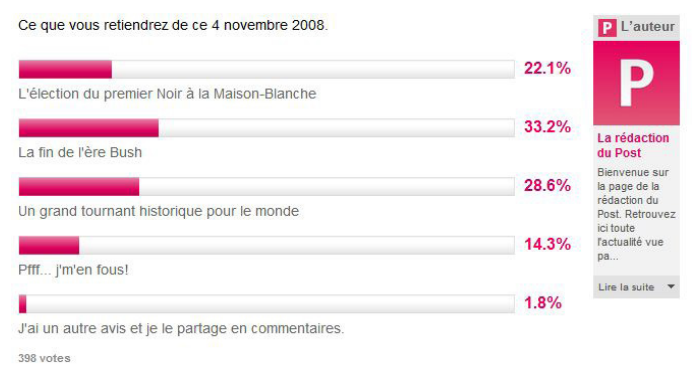

Image 4. Representation of hyper-marked "the other's" discourse responding to a poll (LePost.fr, 05/11/2008, 09: 46)

\section{3. Reporting the other's speech}

\section{3. 1. Direct speech (DS)}

As we explained when presenting the observable phenomena, we start from the postulate that all the represented discourses, including those in direct mode, are requalified by the reporting speaker. The quoted speeches are not merely reported or reproduced, they are rewritten and staged. We shall give several examples showing a more or less large care of the quoted contents.

Several genres of journalistic speech are considered as representations in DS such as interview or tribune. The tribune is often an identified column as such: we find the column Verbatim in Le Monde and in Libération as well as the columns La Phrase (The sentence), Reactions or Il l'a dit (He said it) in LePost.fr, like in example in (8). We think that this type of representation presents a strong degree of objectivization.

(8) HE SAID IT

Bush: "What a magnificent night for you, your family and your partisans!" (LePost.fr, 05/11/2008, 07: 09) 
This degree of objectivization can be coupled to a moderated degree of subjectivization, thanks to the use of hypertext links, which may value any publication of the editorial staff. In the following example, Mediapart.fr emphasizes audio samples of the speech of Christine Taubira available for consultation on the site, thanks to the link created on the "escort discourse" (Rabatel, 2011): "Here are the audio extracts of this exchange"; which we qualify as "incentive escort discourse" (Simon, 2011).

\section{Vu de France, par la communauté noire}

O5 NOVEMBRE 2008 | PAR LA RÉDACTION DE MEDIAPART
ARTICLE 6 COMMIENAIRES
Quelques heures avant la victoire de Barack Obama à l'élection
présidentielle américaine, Mathilde Mathieu avait rencontré
Christiane Taubira, mardi 4 novembre, dans les couloirs de
l'Assemblée nationale. L'élue de Guyane, noire, a dénoncé le retard
de la classe politique hexagonale, "qui freine des quatre fers»
devant les minorités visibles, alors que les Français seraient
désormais "preneurs». L'ancienne candidate à la présidentielle de
2002 (parti radical de gauche) a appelé ces dernières à "pulvériser
les directions conservatrices des partis», de gauche comme de
droite. Voici les extraits sonores de cet échange.

Seen from France, by the black community. A few hours before Barack Obama's victory at the American presidential election, Mathilde Mathieu met Christine Taubira, in the corridors of the Assemblée Nationale. The elected representative of black Guyana denounced the backwardness of the hexagonal political class "which jams on the brakes" in front of visible minorities, although French peoples would henceforth "be accepting". The former candidate to the 2002 presidential election (Radical Left Party) has called these last ones "to pulverize the conservative directions of the parties", at the left as well as at the right wings. Here are the audio extracts of this exchange.

Image 5. Valuing hypertextual link (Mediapart.fr, 05/11/2008)

Finally, the use of the direct mode allows the reporting speaker to implicitly direct his speech. In example (9), the journalist of Rue89.com reports a pseudo-dialogue ending with the quotation of a specialist he seems to agree with: 
(9) Historic, moving, happy: the entrance of Barack Obama to the White House proves that this question [of his skin color] was not the most important. Would America accordingly have changed? "No, answers Vincent Michelot, Europe sees with difficulty what changes in the United States. About the Bradley effect, we made a mistake, the country changed about twenty years ago! The stake was e-co-no-mic." (Rue89.com, 05/11/2008, 18: 34)

\section{3. 2. The autonymic modal shaping of borrowings (AMSB)}

The AMSB allows the reporting speaker to distance himself from a part of the represented speech. Thanks to the use of quotation marks and italics, this process aims at showing, as in (10), that the journalist of Libération does not accept the choice of the used terms.

(10) Trapped by microphones remained open in July, he [Jesse Jackson] had then assured that he would like "to cut off the balls" of Obama whom he considered too arrogant with Blacks. (Libération, 06/11/2008, p. 9)

We guess that the aim is different for LePost.fr $(05 / 11 / 2008$, 12: 28), which chooses to represent this event of speech in DS - by publishing the video -in order to get a spectacular anecdote.

Then the processing of Obama's election illustrates the current tendency of journalistic writing to represent more and more split up discourses, both in printed press and in online one. So the multiplication of several AMSB in a single paragraph is observed very frequently. The discourse represented in example (11) is built with 3 different AMSB. Unlike the use of a simple quotation which would sum up the whole represented speech of Nicolas Sarkozy, the journalist uses a means giving to his processing a personal enlightenment.

(11) On Wednesday, Mr. Sarkozy greeted the "brilliant victory" of Mr. Obama to whom he sent a letter. He applauded "the message of the American people", that "of open, united and strong America, which will show the way, with her partners, by the strength of the example and the agreement with its principles". (LeMonde.fr, 06/11/2008, 13: 43) 
The representation of numerous text blocks referring to the "obamania" - an example is given in (12) - to the "change" (13), to the "American dream" (14), as well as to a "historical event" (also in 13), is finally characteristic of the whole processing by the OLI, OLB and printed press.

(12) The American media quickly evoked an "obamania". (Le Monde, 06/11/2008, p. XI)

(13) "The change" - Obama's slogan of campaign - has become really historical this time. (Liberation.fr, 05/11/2008, 06: 51)

(14) It is the incredible outcome of the dream of Martin Luther King "I have a dream". (Liberation.fr, 05/11/2008, 06: 51)

These "formulae" circulate a lot in the interdiscursive mass of the studied speeches of press. Several variants may be found: "hope of change", "candidate of the change", "historic change", "real change"; "dream"; "historic evening", "historic moment", "historic turning point", "historic triumph", "historic victory", "historic success", "historic election". Some are parts of the collective memory and do not need to mention their enunciative origin. This contributes to what Maingueneau (2004) calls "particitation", meaning a particular way of quotation's process aiming at hiding the original speaker to facilitate its circulation. On the other hand, as underlined by Charron and de Bonville (2004), let us specify that this "particitation" complies with two constraints: the first, ,spatial one, is named "the interval of intertextuality" (Charron \& De Bonville 2004, p. 199), and the second temporal one called "area of intertextuality" (Charron \& De Bonville 2004, p. 200). We can note that these formulae circulated at international range with a rather long distribution time for some of them, like "obamania" for instance. On the other hand, "change" is a formula getting back by numerous politicians.

1 The "formula" is defined by Krieg-Planque as "a set of formulations which, because of their uses at a given moment and in a given public place, crystallize political and social stakes which these expressions contribute at the same time to build" (2009, p. 7). 


\section{3. 3. The modal shaping of the speech as second discourse (MSSD)}

MSSD is rather little observed in the columns of the studied newspapers, both in the printed press and in online news. To mark a distance, it can use the conditional mode - as in (15) -, and reinforce it by addition of a mediator to specify the source -like "according to", in (16).

(15) And from Wednesday morning, Barack Obama would have asked the Democratic Representative Rahm Emanuel, another former member of Clinton's team, to take General Secretary's responsibility at the White House. (LeMonde.fr, 06/11/2008, 13: 53) [Author's emphasiswe underline]

(16) Obama could appoint the current Republican Governor of California [Arnold Schwarzenegger] to the key-post of Chief of the department of Energy, who is in charge of the energy policy and the American nuclear safety, according to Politico.com. (LePost.fr, 05/11/2008, 12: 42) [Author's emphasiswe underline]

\section{3. 4. Indirect speech (IS)}

At last, IS allows the reporting speaker's speech personalization, since he rephrases the represented speech with his own words. In example (17), thanks to a spun metaphor ("tune", "intoned", "resound", "conductor", "stanza"), the journalist of Liberation not only reports speech, but assimilates in a very subjective way Obama's speech to a song.

(17) The tune of this rallying ideal was already intoned by the others in the past, but Barack Obama embodies it. He makes it resound, like a conductor does, in the fervent ears of the Americans. Half-blood, he adds a new post-racial stanza to it. (Liberation.fr, 05/11/2008, 06: 51)

The indirect mode commits the enunciative responsibility of the journalist. It is represented in an equivalent way in the treatment of the OLI, OLB and printed press. In the following example, it is surprising to see that the choice of the term animal is assumed as such: 
(18) With Obama, Nicolas Sarkozy has in front of him an animal which he estimates to be of his caliber. (Liberation, 06/11/2008, p. 24)

\section{4. Representation of others discourses in resumption}

\section{4. 1. RRD in titles}

The day after Obama's election, number of ORD were reused as titles. Tuomarlà (1999, pp. 106-107) calls the result of this process "quotation-title". It is a common strategy to turn these speeches to "events of speech". It is also a way to suspend the enunciative caretaking to guarantee the visible neutrality of the journalist. For example:

(19) An inverted September-11

(19') It is nevertheless on this ground of the reconciliation that the elected president is most expected in countries far from the United States. For Frédéric Martel, the advent of Barack Obama will stay "as a positive date" in the contemporary history, a kind of "inverted September-11". (Le Monde, 06/11/2008, p. V)

In this representation of in-resumption discourses, quotation marks bound the represented speech, even if it has been processed by the journalist. The aim of these additions of RRD is less to be informative than to trap. This creates a relation of complicity with the public.

\section{4. 2. RRD in subheads}

Le Figaro and especially Liberation very often use the RRD in subheads, with or without quotation marks. They allow thematic transitions in the article to facilitate the reading. The example (20) illustrates the representation of a speech in resumption ("pastel America") which rephrases the ORD (20'):

(20) Pastel America

(20') This last week, the senator of Arizona was forced to defend lands which voted for Bush in 2000 and 2004, rather than to concentrate on the decisive States to be conquered. "One of the lessons of the last months, is that the battlefield between Republicans and Democrats considerably widened, notes Robert 
Shapiro, it is not any more completely red America on one side, and blue America of the other side, it is another America in less marked colors, more pastel." (Liberation.fr, 05/11/2008, 06: 51)

As for the quotation-titles which have an incentive character, the RRD in subheads tries to surprise, to intrigue the public, by diverted formulae.

\section{4. 3. RRD in special insert boxes}

Then RRD are often present in special insert boxes which voluntarily intrude the layout of the article. They typically illustrate this paradox: a strategy of stage-setting vs. an enunciative disengagement. In the printed issue of Liberation, the text is emphasized with the increment of the letters' bolding and the use of the red color. At first sight, those representations may be taken for hyper-marked the other's discourse representations, but it is not the case.

Besides, let us note that it is not surprising that these special inserts are non-existent in the online versions of Le Figaro and Liberation. It's the same for the addition of certain quotation titles, like in the online version of the text quoted in (6), where the title "The anti-rumor shield" does not appear (Liberation. fr, 06/11/2008, 06: 51). In fact, OLI articles do not present elements of paratext. The image is generally absent, the introductory paragraph is often eliminated and inserts representing speeches in resumption are absent. This is surprising because an OLI issue has a lower degree of subjectivization than the one of printed version.

\section{5. Open positioning}

The editorial, especially present in the printed press, is an ideal genre to present an open positioning towards the point of view of another speaker. Here is an example where the editorial writer of Libération aligns his arguments with the slogan of Obama, and takes ownership of them, as shows the end of his editorial:

(21) Will the man prove that he will be up to it? In any case he has the talent for it. Yes, he can... (Libération, 06/11/2008, p. 2) 
In the column Rue69.com, of the site Rue89.com, we find another very subjective interpretation of the slogan. According to the author of "Yes we can, from election to erection" article, Obama "gives a hard-on to the world" (Rue89.com, 05/11/2008, 12: 22). By using a hypertext link, she refers the readers to a kind of online sex-shop which sells dildos in the shape of Barack Obama.

Here isanother interesting positioning can be underlined, found in the editorial of Le Figaro:

(22) An American Black is first of all an American who believes in his country and sings the national anthem with the hand on the heart. We must meditate this example, as Brice Hortefeux, indeed, suggests teaching La Marseillaise and the values which it represents to the immigrants settling down in France. Not so long ago, such a suggestion would have seemed "reactionary". Today we wonder if she is not eminently progressive. (Le Figaro, $06 / 11 / 2008$, p. 23)

The text-block "reactionary" does not mention the enunciative origin, but this is of small importance considering the argumentative aim targeted by the editorial writer: for him, the election of Obama is the opportunity to praise the political projects of the UMP party.

Again, about the text-block "historical", a journalist from Le Monde clearly stands about the justified use of this expression in the context of Obama's election. Here is a part of the transcription of his oral speech, available for consultation on the site:

(23) Listen, in print media, we are particularly attentive not to tarnish the meaning of the words and I think that in that case, it is not so. The "historic" adjective seems to me particularly well chosen. [...] (LeMonde.fr, 05/11/2008, 12: 53)

The rejection of the represented speech is one form of opened positioning observed in LePost.fr. In example (24), the contributor ("wentour") does not hesitate to resume the represented discourse ("rotten") to point out the represented speakers:

(24) The "rotten" will always be stronger... "Obama will surely have an influence, but from there to change the world, no, I do not think so. People who want to remain rotten will stay so. And 
Obama will be able to do nothing there" by wentour. (LePost.fr, 05/11/2008, 13: 20)

Finally, here is another example from the OLB LePost.fr, an extract of a press review aiming for subjectivization. The criticism concerns the front pages of certain French newspapers published when the election of Obama was announced.

(25) 1 . The most audacious

Le Canard Enchainé straight out anticipated the victory of Obama by titling on the front page: "America is no more afraid of the Dark!" (in French: "L'Amérique n'a plus peur du Noir !"). A winning gamble for the satiric newspaper, which took risks but which in the end, had got the good "feeling"! (LePost.fr, 05/11/2008, 13: 16)

\section{Conclusion}

To conclude, through the analysis of our corpus which approaches the question of journalists' positioning towards their enunciative sources, we can say carefully that professional techniques of writing change little from printed to online press. The quantitative analysis of representation's modes of the other's discourses shows that in printed, OLI and OLB press, the degree of objectivization is higher than the one of subjectivization. For the three kinds of media, it induces the presence of a predominantly objectivating enunciation contract. Thus, the only observed positionings are either identified in the subjectivating genre, such as the editorial, or found in the discourses of contributors who do not claim to be information professionals.

Subsequently, by means of qualitative analysis, we note that the rhetoric of objectivity, appropriate for information journalism, is hardly free from an aim of trapping. We could observe several examples illustrating this paradoxical aim, where objectivization and subjectivization cannot be separated: for instance, when the representation of hyper-marked discourses is juxtaposed with photographs, or when in-resumption marked speeches are represented in titles with incentive characters.

Thus, the new Web system does not seem to question these practices of writing. Besides, the heterogeneousness of discourses using several types of codes, more heavily represented on the Web, 
offers a stage-setting of information which strengthens the relation of complicity with the readers. However, the representation of audio or audiovisual discourses is not necessarily synonymous to an increased level of subjectivization.

After all, the thorough observation of representations' modes of enunciative sources allows us to partially answer our question of journalistic enunciation contract. It would be interesting to complete this study with a meticulous observation of all the marks of interlocution's enunciative relationship with the audience (questionings, incitements, etc.), which could bring new directions for analysis and comparison between printed and online press.

\section{References}

Amossy, R. (2000). L'argumentation dans le discours. Discours politique, Littérature d'idées, Fiction. Paris : Editions Nathan Université.

Authier, J. (2004). La représentation du discours autre : un champ multiplement hétérogène. In S. Marnette, J.-M. Lopez-Munoz \& L. Rosier (Eds.), Le discours rapporté dans tous ses états : question de frontières. (pp. 35-53). Paris : L'Harmattan.

Brin, C., Charron, J., \& De Bonville, J. (2004). Introduction. In C. Brin, J. Charron \& J. De Bonville (Eds.), Nature et transformation du journalisme. (pp. 1-31). Laval : Presses Universitaires de Laval.

Cardon, D. (2010). La démocratie Internet. Paris : Seuil.

Charaudeau, P. (2006). Discours journalistique et positionnements énonciatifs. Frontières et dérives. Semen, 22, 29-44.

Charon, J.-M., \& Le Floch, P. (2011). La presse en ligne. Paris : La Découverte.

Charron, J.-M., \& De Bonville, J. (2004). Typologie historique des pratiques journalistiques. In C. Brin, J. Charron \& J. De Bonville (Eds.), Nature et transformation du journalisme. (pp. 141-217). Laval : Presses Universitaires de Laval.

Genette, G. (1987). Seuils. Paris : Seuil.

Grevisse, B. (2008). Ecritures journalistiques. Stratégies rédactionnelles, multimédia et journalisme narratif. Bruxelles : Editions De Boeck Université.

Krieg-Planque, A. (2009). La notion de "formule » en analyse du discours. Besançon : Presses Universitaires de Franche-Comté.

Maingueneau, D. (2004). Hyperénonciateur et 'particitation'. Langages, 156, 111-127.

Mercier, A. (2010). Défis du nouvel écosystème d'information et changement de paradigme journalistique. Mis en ligne en décembre 2010, http://obsweb.net.

Mouriquand, J. (1997). L'écriture journalistique. Paris : PUF.

Peytard, J. (1993). D'une sémiotique de l'altération. Semen, 8, 143-177.

Rabatel, A. (2011). Analyse énonciative des s/citations du site d'Arrêt sur images. In A. Jaubert, J. López Muňoz, S. Marnette, L. Rosier \& C. Stolz (Eds.), Citations II, Citer pour quoi faire? Pragmatique de la citation. (pp. 13-36). Louvain-La-Neuve : Harmattan-Academia. 
Rabatel, A. (2004). L'effacement énonciatif dans les discours rapportés et ses effets pragmatiques. Langages, 156, 3-17.

Rosier, L. (2008). Le discours rapporté en français. Paris : Ophrys.

Simon, J. (2012). Circulation interdiscursive dans la presse française au lendemain de l'élection de Barack Obama. Le discours et la langue, 2-2, 99-112.

Simon, J. (2011). Analyse des liens hypertextes sur le site Mediapart dans l'affaire Woerth/Bettencourt/Mediapart. In I. Saleh, L. Massou, S. Leleu-Merviel, Y. Jeanneret, N. Bouhai \& P. Morelli (Eds), H²PTM 2011, Hypermédias et pratiques numériques. (pp. 153-164). Paris : Hermès-Lavoisier.

Tuomarlà, U. (1999). La citation : mode d'emploi. Sur le fonctionnement discursif du discours rapporté direct. Tuusula/Helsinki : Academia Scientiarum Fennica.

Verón, E. (1985). L'analyse du « contrat de lecture » : une nouvelle méthode pour les études de positionnement des supports presse. In Médias : expériences, recherches actuelles, applications. (pp. 203-230). Paris : IREP.

Vion, R. (1998). Du sujet en linguistique. In R. Vion (Ed.), Les sujets et leurs discours. Enonciation et interaction. (pp. 189-202). Aix-en-Provence : Publications de l’Université de Provence. 